\title{
THE VINDICATION OF A NATIONAL PUBLIC POLICY UNDER THE FEDERAL EMPLOYERS' LIABILITY ACT
}

\author{
MeIVIN L. GrifFith*
}

I

When William Bradford, Governor of Plymouth Colony, wrote his history of "Plimouth Plantation," he felt it necessary to introduce his subject by saying that he must "begine at ye very roote and rise of ye matter." If there has been failure to understand fully what Congress undertook to accomplish by the legislation designed to give relief to men engaged in operative railroading, it is due to the fact that there has been little, if any, inclination anywhere to get at "ye very roote and rise of ye matter."

It is not new or unusual that the legislative necessity for the declaration by government of national public policy, in the interest of justice and the public welfare, arises out of the nature and importance of some particular undertaking, business or vocation-its hazards, its isolation, its limited or farflung field of operations, and the importance of the contribution made by those so engaged to social, political and economic progress. Whether such a public policy, based upon these and other factors more or less potent, is expressed in usage, custom, and practice, or in constitutions and statutes, its claims to continued public approval must rest upon its social value, as proved through time and experience. The survival of such a policy expressed in a statute, in the face of continuous and concerted attack upon it by those who profess a philosophy hostile to it and by powerful interests claiming to be adversely affected by it, through long periods of time during which the policy has been steadily strengthened and broadened by the law-making body which declared it and by the courts charged with the duty of construing it, constitutes the strongest proof of the soundness of the policy.

In seeking to appraise the social, political and economic value of a public policy in the interest of those engaged in a particular vocation, it is not enough to point to some other class or group in society which is not given similar privileges. The search for sustaining or destructive factors must be directed at the peculiar problems and the contribution to social progress of the group benefited. The modern rules and practices in admiralty, for example, have their origin in ancient usage,

* B.S. in Education I915, University of Missouri. Superintendent of Schools, Breckenridgc, Mo., 1915-1917. Ph.B. 1919, J.D. I920, University of Chicago. Admitted to Illinois bar, October 1920. Member of Chicago Bar Association and admitted to practice in federal courts in Illinois since 1920 and in the Supreme Court of the United States since 1937. Practiced law in Chicago, Ill., since 1920. Member of firm of Winters, Stevens, Risk and Griffith, 1923-1930; Stevens, Carrier and Griffith, 1930-1936; practiced alone, 1936-1942; since I942 associated with firm of Henslee, Monek \& Murray, and with Edward B. Henslee, General Counsel of the Brotherhood of Railroad Trainmen. 
custom, and practice developed and proved through time and experience, as best suited for use in the government of men who earned their livelihood on the seas. Such rules and practices, it is said, were first collected into manuscript and established as a public policy with reference to seamen, by the inhabitants of the little island of Rhodes. These ancient laws of the sea developed, through centuries, into a system of jurisprudence so different from that which governed those who earned their livelihood on land that the Roman Emperor, Augustus, could declare: ${ }^{1}$

I am the master of the earth, but the Rhodian law is mistress of the sea.

In admiralty today, in the United States, the seaman who seeks there a vindication of the rights guaranteed to him by admiralty law, is treated as a ward of the court. ${ }^{2}$ It is not without significance that when Congress gave to seamen an additional remedy in the law courts, it granted to them the benefits of the same national public policy it had declared for railroad men in the Federal Employers' Liability Act. ${ }^{3}$

Transport, either upon land or upon the sea, has always determined whether social, political and economic life should be local or national. The most potent factor in the revolutionary change from feudalism to nationalism, was the improvements in transport by sea and by land. Introduction of the locomotive and the railway, in the nineteenth century, inaugurated a social and economic revolution. The railways, followed in turn by the steamship, the telegraph, the telephone, the automobile, the aeroplane, and radio communication, transformed the world. The importance of the railway in the development of our own country was within the vision of its pioneers. In 1828 , one of those pioneers, Charles Carroll, the sole survivor at that time of that great group of patriots who signed the Declaration of Independence, turned the first spade of earth in the construction of the Baltimore and Ohio Railroad, at Baltimore, Maryland. He made a speech that day in which, referring to his act of turning that first spade of dirt in the construction of what is now one of our great railroad systems, he said: ${ }^{4}$

I consider this among the most important acts of my life; second only to my signing of the Declaration of Independence; if even it be second to that.

When Charles Carroll uttered these significant words, there were approximately 23 miles of railroad in the United States. The opening two years later of the few miles of railroad, the construction of which was launched by that vital spade of dirt, by the Baltimore and Ohio and of the first few miles of the South Carolina Railroad, grown now into the great Southern Railway System, was the real beginning of the railway epoch-the age of man's most significant advancement. Nearly forty years later, May I0, 1869 , the glory and the achievement of that era were symbolized

\footnotetext{
${ }^{2}$ James Henry Willock, Commentary on Maritime Workers, United States Code Annotated, Titue 46, pp. 211,214 .

${ }^{2}$ See Isbrandtsen Co. v. Johnson, 343 U. S. 779 (I952).

${ }^{3} 38$ Srat. II85 (r915), as amended, 4I STAT. I007 (1920), 46 U. S. C. $\$ 688$ (I946); Garrett v. Moorc-McCormack Co., 317 U. S. 239 (I942).

- Association of American Railroads, Quiz on Railroads and Railroading, Question No. 296 (gth ed. I95I).
} 
by the driving of gold and silver spikes where East met West, at the linking of the Union and Central Pacific Railroads at Promontory, Utah, to form the first great transcontinental steel highway of commerce in America. In the next twenty years it was possible to travel from the Atlantic Coast to the Pacific Coast over at least six different railroad systems. The men who furnished the courage, the genius, and the vision to bring about this transportation epoch in human history, the end of which is still beyond far horizons of the indomitable will and spirit of man, have enduring places in history along with the great navigators of the seas, who discovered not only new routes of trade and commerce, but new worlds to serve as new stages upon which man could work and dream out his destiny.

In the last quarter of the nineteenth century and the first ten years of the twentieth century, the fact that there is another side to this picture of glory and achievement, burst upon the public consciousness. There are the multitudes of men who as individuals have remained ơbscure, but without whom those giant enterprises could have gained neither wealth nor power nor usefulness in the nation's economy. They are the men who hold in their hands the safety of our goods and merchandise when we ship them from one place to another and of our own lives when we go, ourselves, on a journey-the men who have the hazardous job of maintaining the lines and of operating the trains on which we ride or transport our goods. For them, it appeared that these steel paths of glory led but to the grave.

President Harrison, speaking of the plight of these men in his message to Congress in 1889 , said: 5

It is a reproach to our civilization that any class of American workmen, should in the pursuit of a necessary and useful vocation, be subjected to a peril of life and limb as great as that of a soldier in time of war.

As railroads lengthened to traverse state after state of the union and finally to span and spider-web the continent, such regulation as there was in the interest of the safety of the lives and limbs of operative railroad men fell successively to the states through which the lines ran. There was not, nor indeed could there be, any uniformity in such state laws as were placed upon statute books to control or to ameliorate these conditions. The great railroad corporations became laws unto themselves. Railway cars were coupled together with what was known as the link and pin system, requiring the trainmen to step in front of cars or go between them to make the couplings. Cars were equipped with hand brakes, requiring men to go upon moving cars to stop them or to control their speed. In addition, as these dangerous devices and methods began to give way to time-saving and, incidentally, to life-saving coupling, braking, and other devices, such devices notoriously lacked uniformity. This lack of uniformity arising from chaotic state regulation and the great numbers and types adopted by the various railroads in various states contributed greatly to the casualty lists among operative railroad men. A brakeman's

${ }^{5}$ See Johnson v. Southern Pac. Co., I96 U. S. I, I9 (1904); 12 Messages and Papers of the PresiDENTS 5486 (Richardson ed. I897). 
chances of dying a natural death were in $I 888$, I to $4.7 .^{6}$ The average life expectancy of a switchman in 1893 was seven years.

The development and final adoption of the national public policy forecast by the President in his message to Congress in 1889 , is a story of dark and bitter years. The men, themselves, in the face of warnings by their employers that they would lose their jobs for doing so, played a significant role in the process of improving conditions, by organizing themselves into transportation brotherhoods-the Brotherhood of Locomotive Engineers, founded in 1863 ; the Order of Railway Conductors in I868; the Brotherhood of Locomotive Firemen and Enginemen in 1873; and the Brotherhood of Railroad Brakemen, later the Brotherhood of Railroad Trainmen, in $I 883$. These Brotherhoods, strictly speaking, were not in those days labor unions. They were, in fact, fraternal bodies, organized for insurance protection against injury and death in the course of employment. The meager sum that could be paid in fraternal benefits to totally disabled members or to the next of kin of those who were killed was virtually the only protection the men had or could get.

The period intervening between the beginning in America of the railway epoch and the final enactment of the Federal Employers' Liability Act in 1908, saw the rise and fall of laissez faire-the doctrine of non-interference by government in matters concerning labor. That doctrine, under the influence of the philosophy of David Ricardo, the English economist of the late eighteenth and early nineteenth centuries, in which the laborer was regarded as merely a chattel in the hands of capital, bore down with heavy tragedy upon the operating railroadman. He stood helpless and alone under ruthless practices of his railroad employer. He feared even to approach his employer except to render beneficial service. He took such wage as was offered, endured such working conditions as he found, and, in fear, obeyed such rules as were made by management. When he became a casualty of his hazardous employment, he took what his employer offered him, which, if indeed any offer at all was made, was so inadequate as to bear no relation to the damages suffered. There was, of course, the common-law right of action in court open to him, for damages resulting from his employer's negligence, in case he determined not to accept the amount, if any, offered him in settlement of his claim. If he chose to follow that course, he found that his employer could there urge judge-made defenses that, for all practical purposes, insulated the employer from bearing any of the cost of the human overhead of this highly hazardous business-the fellow-servant rule, contributory negligence as a bar to the action, and assumption of risk. He might also be met there by some contract or device by which the employer had successfully exempted itself from liability.

The real essence of the national problem, presented by the growing casualties among railroad men and the consequent burden that was cast upon these workers and their families, was to resolve the sharp conflict between the brutal philosophy of Ricardo and the humanitarian doctrines of the great social philosophers of the

\footnotetext{
o Third annual Report of the Interstate Commerce Commission 85 (1889).
} 
time in favor of this important group of men who earned their livelihood on land. It was a dramatic demonstration of these sharply conflicting views in the period when the states, alone, were frantically seeking answers to the appalling casualties among operative railroad men that lighted a torch and placed it in the hands of a man who, with the aid and backing of five presidents of the United States and of the railroad Brotherhoods, became the father of the federal Acts declaring this national public policy. A bill requiring grab irons, as a safety measure, to be placed upon freight cars was introduced in the Massachusetts legislature and was assigned to a joint committee of the two Houses to hold hearings on the proposal. A railroad official at the hearing denounced the proposal as an outrage. "Why," the official exclaimed, "every time a fellow grabbed that thing, he would give the car such a wrench, it would spring a leak and ruin the contents." The objector was thinking of the leaky car and the bill for damaged merchandise and not of the trainman who might seize the grab iron only to save his life.

A member of the legislature and of this joint committee, was Edward A. Moseley. He was not a railroad man. In his early life he was a seaman. The effect upon him of the grab iron incident led him into his real life's work-that of securing federal relief for operative railroad men.

The Interstate Commerce Act was passed by Congress, March 7, 1887, as the inevitable result of the proved inability of state governments to deal with even the ordinary problems of commerce between the several states. That Act created the Interstate Commerce Commission, as the corporate agent of the Federal'Government with administrative and quasi-judicial power over the railroads operating in interstate commerce.

Mr. Moseley became the first Secretary of the Commission in 1887 . In the first year of his secretaryship he caused the Commission to employ a statistician; in his second year, with the statistician's report in his hands, he began to inform the public about the high casualties in railroading. On January $3 \mathrm{r}$, I889, he called a conference of all state railroad commissioners to be held at the office of the Commission in Washington on March 5, I889. The conference was attended by representatives of every state and territory with but few exceptions. One of the major questions discussed was safety appliances in railway transportation. A resolution was unanimously adopted by the Conference urging the Commission to develop and recommend national measures that would give relief to railroad employees, thousands of whom were being injured and killed every year. Pursuant to this resolution, on May I7, I889, Mr. Moseley addressed a circular relating to federal regulation of safety appliances on the railroads to all state railroad commissioners, to the principal officers of railway companies, to the railroad transportation Brotherhoods, and to other important groups and individuals. The state railroad commissioners, with few notable exceptions, favored such federal regulation. The Brotherhoods gave

' James Morgan, The life Work of Edward A. Moseley in the Service of Humanity 57 (1913).

${ }_{24}$ Stat. 379 (I887), as amended, 49 U. S. C. \$I et seq. (I946). 
strong support to the proposal as did the Master Car Builders Association, The Engineering Journal, and many civil engineers and other interested and farseeing individuals. The Brotherhood of Railroad Trainmen, then the Brotherhood of Railroad Brakemen, in addition to a strong-favoring letter to the Commission, filed a Petition addressed to the Commission in which it was said: ${ }^{8}$

Each of the undersigned is in actual service as a railroad brakeman or has been employed a sufficient length of time to become fully acquainted with the duties and perils of the position, and although some of us have been promoted, we most earnestly appeal to your honorable body to urge upon Congress the necessity of national legislation in this matter, that the terrible slaughter of brakemen on the railroads of this country every year may be largely diminished.

The railroads which answered the circular were in unanimous opposition to the Commission's proposal of federal regulation.

The national public policy, forecast by the arresting description of conditions by Mr. Moseley and by President Harrison in his 1889 message to Congress, had been initiated. These historic steps and events led through Mr. Moseley's continued pressure and the growing public concern and demand for relief, to the enactment by Congress in 1893 of the original Federal Safety Appliance Act. ${ }^{10}$

Mr. Moseley did not stop there. The Brotherhood of Railroad Trainmen held its First Biennial Convention at Boston, Massachusetts, in October 1893. It held a public reception there on October $\mathrm{I} 7$, at which the governor of Massachusetts, the mayor of Boston, Edward A. Moseley, L. S. Coffin, and the executive officers of the labor organizations of the country gave addresses. Mr. Moseley in his address said in part: ${ }^{11}$

There is something appalling in the statement that more hard-working and faithful railway employees in the United States, went down in sudden death last year than the entire number of Union men who died at the Battle of the Wilderness; nearly as many as those who died the bitter death at Spottsylvania; more than three times the number of the Union dead at Lookout Mountain, Missionary Ridge and Orchard Knob combined, and that more of the grand army of railway men of this country were cut and bruised and maimed and mangled last year than all the Union wounded and missing on the bloody field of Gettysburg; nearly equal in number to the wounded and missing in the reign of death and devastation at Shiloh, first and second Bull Run and Antietam combined; while there traveled under the care and guidance of this clear-headed and vigilant army of railway workers $560,95^{8,21 I}$ passengers with so much ease and safety that only one in every $1,491,9$ ro was killed and only one in every 173,833 was injured from all causes, including their own carelessness.

We are standing upon the shores of the Atlantic. Looking to the east we behold a broad expanse of water. Upon this coast-within sound of the roar of the surf-not a storm arises but a prayer goes up from the good housewife for the safety of the poor sailor struggling with the elements. Why is this solicitude so fervently expressed?

o Third annual Report of the Interstate Commerce Commission 340 (I889).

1027 STAT. 53I, 45 U. S. C. $\$ \$ I-7$ (I946). $60-62$.

21 Io Rarlroad Trainmen's Journal 930-939, 853 (Oct. 1893); Morgan, op. cit. supro note 7, at 
From time immemorial the limitless deep has been associated with peril to human life, and the most anxious feelings of our race have been evoked in behalf of those "who go down to the sea in ships." For centuries every civilized language has, in prose and poetry, extolled the heroism of the sailor, and sympathized with the dangers and sacrifices of the toiler who earns his livelihood upon the unstable elements. The sound of the waves and the heavy blasts call attention to the fact and tend to perpetuate one of the finest traits in our human nature-a brotherly interest in the welfare of a worthy portion of the community.

And yet, how little of this commendable sympathy is bestowed on the equally brave and far more exposed toiler working in the freight yard or on the raill $\mathrm{He}$, too, is traveling a deck. To be swept from it will hurl him to eternity in a far more sudden and agonizing way than the poor fellow carried by a wave from the deck of a vessel. The latter, in many instances, has a chance-with the help of a resolute heart and sinewy arm - of rescuing himself from a watery grave. How vast the difference with the victim of the railway, the great modern agent of civilization, as essential to human intercourse as the ship has been since the earliest times!

Yet dangers to the trainmen do not come home to the good people. Their attention has not yet been sufficiently awakened to the subject. Let them think of the fated fellow who slips between the cars and whose only possible escape is by a desperate grasp at their icy sides; or of him who, swept from the running board of the rapidly moving car, is hurled to instant and certain destruction.

Dangers beset him everywhere. As he works amid an intricate warp of iron-rails, the next step may fasten his heel in the deadly unblocked frog, holding him in a vise, suffering an agony of suspense, while the wheel bears down upon him to mangle his poor body and crush his life out.

Let people reflect that it requires fully as much courage and nerve to peer out into the darkness and catch sight of a few feet of gleaming rails in front, all else the blackness of night, as it does to stand on the bridge of a ship and with straining eyes endeavor to avoid the passing vessel, the derelict, or the iceberg.

In I895, two years later, he caused the first Employers' Liability Act to be introduced in Congress as a sort of trial balloon. He drafted the bill and aroused such interest in its objectives that he was able to enlist the vigorous support of President Theodore Roosevelt who drove it through the Fifty-Ninth Congress in I906.12 Congress, committed to the purpose of the law, which in January 1908 was held unconstitutional, ${ }^{13}$ under the lash of several vigorous messages from the President, enacted the constitutional Act three months later, April 22, rgo8. ${ }^{14}$

The original Safety Appliance Act of 1893 was extended and strengthened by many amendments, beginning in 1896 and continuing through $1940 .{ }^{15}$ In I910 Congress amended the $\mathrm{Act}^{16}$ by adding Sections II-I 6 to impose upon the Interstate Commerce Commission the duty of adopting rules and regulations designating and standardizing the number, dimensions, location, and manner of application of all safety appliances on all railroad cars and other equipment. Pursuant to the Act as

\footnotetext{
1234 STAт. 232 (I906).

${ }^{13}$ 'The Employers' Liability Cases, 207 U. S. 463 (1908).

14 35 STAT. 65 (1908), 45 U. S. C. \$\$5I-60 (I946).

1627 STAT. 53I (r893), as amended, 45 U. S. C. $\$ \$ \mathrm{I}-46$ (I946).

${ }^{10} 36$ StAT. 298 (1910), 45 U. S. C. \$\$II-16 (1946).
} 
thus amended, the Interstate Commerce Commission made its order of March $\mathrm{r}_{3}$, xgrI, standardizing all safety appliances and equipment. ${ }^{17}$ These rules and regulations are integral parts of the Safety Appliance Act and have the force of law..$^{18}$

Under the Federal Employers' Liability Act of 1908, venue was left by Congress under the then general venue statute for federal circuit and district courts. That statute provided:19

... no civil suit shall be brought in any district court against any person by any original process or proceeding in any other district than that whereof he is an inhabitant; but where the jurisdiction is founded only on the fact that the action is between the citizens of different States, suits shall be brought only in the district of the residence of either the plaintiff or the defendant.

An employee suing under the Act was thus compelled to sue his employer in the state where it was incorporated. By I9ro, litigation under the Act in the intervening two years convinced Congress that this limitation as to venue was unjust to the employee, and in that year the present venue clause was added to the act. The amendatory bill, as first drawn, made causes of action arising under the Act completely transitory by fixing venue as: ${ }^{20}$

... the district of the residence of either the plaintiff or the defendant, or in which the cause of action arose, or in which the defendant shall be found at the time of commencing such action.

It was considered that this language gave too wide a choice and might result in injustice to the carrier. The language adopted, after much debate, was: ${ }^{21}$

Under this chapter an action may be brought in a district court of the United States, in the district of the residence of the defendant, or in which the cause of action arose, or in which the defendant shall be doing business, at the time of commencing such action.

Senator Borah of Idaho, in charge of the amendment in the Senate, in stating its purpose and scope said:22

The bill enables the plaintiff to find the corporation at any point or place or state where it is actually carrying on business, and there lodge his action, if he chooses to do so.

It was in connection with this vital amendment to the original Act that the national public policy declared by the Act was fully expressed in Congress: ${ }^{23}$

This subject is referred to here only for the purpose of calling upon Congress to make entirely manifest the good faith of the legislature in the enactment of the employers' liability law, which places such stringent liability upon the railroads for injuries to their employees as to compel the highest safeguarding of the lives and limbs of the men in this dangerous employment. The tremendous loss of life and limb on the railroads of

1749 Code Fed. Regs. Parts 13 I-136 (1949).

${ }^{18}$ Lilly v. Grand Trunk Western R. R., 3 I7 U. S. 48 r, 488 (I943).

${ }^{10} 36$ STAT. II68 (IgIr), 28 U. S. C. \$II2(a) (1927).

3045 Cong. Rec 2253 (rgio).

${ }_{21} 36$ STAT. 29x (19ro), as amended, 45 U. S. C. $\$ 56$ (1946).

2245 Cong. Rec. 4034 (1910).

${ }^{23}$ Id. at $404 \mathrm{r}$. 
this country is appalling. The total casualties to trainmen on the interstate railroads of the United States for the year $I 908$ was $28 \mathrm{r}, 645$.

It was the intention of Congress in the enactment of this law originally and it may be presumed to be the intention of the present Congress, to shift the burden of the loss resulting from these casualties from "those least able to bear it" and place it upon those who can, as the Supreme Court said in the Taylor case (2ro U. S. 28I), "measurably control their causes."

The passage of the original act and the perfection thereof by the amendments herein proposed stand forth as a declaration of public policy to radically change, as far as congressional power can extend, those rules of the common law which the President, in a recent speech at Chicago, September I6, I909, characterized as "unjust." President Taft in his address at Chicago, September 16 , 1909, referred "to the continuance of unjust rules of law exempting employers from liability for accidents to laborers."

This public policy which we now declare is based upon the failure of the common-law rules as to liability for accident, to meet the modern industrial conditions and is based not alone upon the failure of those rules in the United States, but their failure in other countries as well. ...

The passage of the law was urged upon the strongest and highest considerations of justice and promotion of the public welfare. It was largely influenced by the strong message of President Roosevelt to the Sixtieth Congress in December, I907, in which the basis of the legislation was clearly and strongly placed upon the ground of justice to the railroad workmen of this country and in which legislation was urged to the limit of congressional power upon this subject.

These expressed purposes of Congress and the policy thus announced did not meet with a friendly reception by the courts. After the adoption of the rgro amendment, the Employers' Liability Act ran the rapids of streams of restrictive interpretations and of constructions placed upon its provisions by the courts which reimposed many of the old common-law defenses that, in the original Act, it was the intention of Congress to abolish. The Act was so battered and damaged at the hands of the courts by I939 that further rehabilitation and repair by Congress became essential. The I939 amendment repaired the damage to the Act's provisions that had resulted from its turbulent passage through the courts. That amendment made the purpose of Congress in passing the law in the first place so clear and positive as to leave no reasonable loophole for further innovations by the courts. ${ }^{24}$

The Supreme Court of the United States, in an impressive series of decisions rendered subsequent to the I939 amendment and under the unmistakable authority of its provisions, has written what may be accepted as the brightest page in the long struggle of operative railroad men to achieve justice and an equal position of bargaining power with their powerful employers in securing adequate safeguards to life and limb and adequate compensation for wrongful injury and death in the course of their highly hazardous employment. The court placed the capstone upon the policy of national regulation of matters concerning the welfare of this important group of men who earn their livelihood on land, by welding together as the founda-

${ }^{24} 53$ STAT. I404 (I939), 45 U. S. C. $\$ 5$ I (I946); see Mr. Justice Douglas' concurring opinion, Wilkerson v. McCarthy, 336 U. S. 53,68 (I948). 
tion of that policy the two branches of the legislation in which the national policy is declared. In Urie v. Thompson, the Court placed the Federal Safety Appliance Acts in pari materia with and supplemental to the FELA and said: ${ }^{25}$

In this view the Safety Appliance Acts, together with the Boiler Inspection Act, are substantively if not in form amendments to the Federal Employers' Liability Act. They dispense, for the purposes of employees' suits, with the necessity of proving that violations of the safety statutes constitute negligence; and making proof of such violations is effective to show negligence as a matter of law. Thus taken, as has been the consistent practice, the Boiler Inspection and Safety Appliance Acts cannot be regarded as statutes wholly separate from and independent of the Federal Employers' Liability Act. They are rather supplemental to it, having the purpose and effect of facilitating employee recovery, not of restricting such recovery or making it impossible.

Thus, the national public policy forecast by President Harrison in his 1889 message to Congress, like grist from the slow mills of the gods, came to full realization.

\section{II}

In the foregoing pages, it was the purpose of the writer to transpose, as nearly as possible for this present year of 1952 , the view of the conditions out of which this national public policy arose that was held by those men of the past who initiated that policy and wrote it into law. There, in order that we may understand what that policy is, we look forward through their eyes. It is now, after forty-five years since the policy was declared, essential in our appraisal of that policy, to look backward through our own eyes. The laws in which this national public policy was declared, were not self-executing. They were but the ounce of prevention. There still had to be the pound of cure.

The scope of the legislation has been recently defined by both Congress and the Supreme Court. Congress, in the I939 amendment, clearly defined what it meant to do in previous amendments and the original Act: ${ }^{26}$

Any employee of a carrier, any part of whose duties as such employee shall be the furtherance of interstate or foreign commerce; or shall, in any way directly or closely and substantially, affect such commerce as above set forth shall for the purposes of this chapter, be considered as being employed by such carrier in such commerce and shall be considered as entitled to the benefits of this chapter. (Italics supplied.)

Congress here used the all-inclusive language that was used in Section 5 of the original $\mathrm{Act}^{27}$ in defining contracts and devices which it declared void when their effect was to exempt the carrier from "any liability under this chapter." Although the Supreme Court has not directly construed the quoted provision, the Court's interpretation of its all-inclusive language is foretold by the Court's ruling upon the identically all-inclusive language of Section 5 in Duncan $v$. Thompson, where the Court said :28

\footnotetext{
${ }^{25} 337$ U. S. I63, I89 (1949).

${ }^{20} 53$ STAT. 1404 (I939), 45 U. S. C. $\$ 5$ I (I946).

2735 Srar. 65 (Ig08), 45 U. S. C. \$55 (I946).

${ }^{28} 315$ U. S. I, 6 (1942).
} 
Because the various state measures directed against contractual arrangements intended to exempt employers from liability were thus laid before Congress, the rejection of the restrictive language of $\S_{3}$ of the old act indicates a deliberate abandonment of the limitations of that section. And the adoption of $\$ 5$ of the present act, without adding any of the other limitations which some of the state statutes had embodied, argues persuasively that Congress wanted $\S_{5}$ to have the full effect that its comprehensive phraseology implies. (Italics supplied.)

Congress had legislated to the limit of its power over commerce upon the subject. Chief Justice Marshall in Gibbons v. Ogden in defining this power, said: ${ }^{20}$

This power, like all others vested in congress, is complete in itself, may be exercised to its utmost extent, and acknowledges no limitations, other than are prescribed in the constitution.

When Congress, in the circumstances described above, exercised this power in the enactment of these laws originally and in strengthening them through amendments, it left no element of justice to railroad workmen in that field, unprotected. But, inevitably, the benefits under the Acts accrued only to those workmen, or to their next of kin, who could successfully invoke the provisions of the laws to enforce the rights and privileges therein granted. Edward A. Moseley, who with the assistance of the Brotherhoods, had initiated, drafted, and caused these laws to be introduced in Congress, and who so skillfully and persistently engineered them through the legislative mill, was also the first to realize the handicap under which the workers and their families must proceed in the enforcement of their rights. They were usually without funds and were ignorant of their rights under the Act. Its enactment found them in despair in the face of their condition and paralyzed by the fear of losing their jobs and such security as was furnished by their wages. Characteristically, Mr. Mosely sought a method of overcoming these handicaps. When the Igo6 Act became law, railroad attorneys promptly assembled to plan a campaign against it in the courts. Mr. Moseley successfully urged upon the government the adoption of a vigorous defense. He prepared a lengthy paper outlining a plan of action and submitted it to the administration. In it he suggested the preparation of a general brief for use as far as applicable in any case that might arise under the law and, in conclusion, said: ${ }^{30}$

It may be a new theory, but is it not well within the province of the attorney-general of the United States, when the constitutionality of any act passed by Congress is called in question, to use the resources of the government to the fullest extent in his power to protect the integrity of that act, particularly when, as in this case, the measure is one which is designed to protect the just rights of a vast body of our country's working citizens, and to relieve them from the disabilities entailed upon them by the failure of powerful railroad corporations to provide suitable appliances and facilities for the protection of the lives and limbs of their employees?

${ }^{29} 9$ Wheat. $x, 9$ (U. S. 1824 ).

30 James Morgan, The Life Work of Edward A. Moseley in the Service of Humanity iog-i 10 (1913). 
His suggestion was taken up at a cabinet meeting and the government agreed to follow Mr. Moseley's plan. In announcing the government's decision to intervene in defense of the law, he said: ${ }^{31}$

I regard this action as one of the most important events in the interest of labor that has ever occurred. Were railway employees, who seek to obtain damages for injuries received, left to their own resources there is no question that the benefits which this law seeks to confer upon them would be neutralized or entirely destroyed by the action of the courts.

The railroad companies have the strongest array of legal talent in the country, and this talent will all be directed toward defeating the ends of any such law as this. No private individual can hope to cope with such power; it will be impossible for any railway employee, who invokes the aid of this law, to employ attorneys who can successfully meet the arguments of counsel for the railroad companies. But with the resources of the department of justice placed at his command, in order to protect the integrity of the law, the railway employee is placed on a plane of practical equality with the railway company, and he is thus insured a square deal.

The United States, through the Attorney General's office, filed briefs amicus curiae, in accordance with this agreement, in both the First and Second Employers' Liability Act Cases. ${ }^{32}$

If the above language of Mr. Moseley was prophecy, its indisputable truth has long since been established. That is not strange, for it is the language of a man who not only knew what was taking place, but could see into the future from the vantage point of thirty years of intimate experience with the problems of operative railroad men, with the attitude of the railroads toward their employees, and with the obtuseness or hostility of many of the courts where such problems were involved. $\mathrm{He}$ knew that, notwithstanding the positive expressions of the law, employees would still be confronted by the same philosophy that revealed itself to him in the startling grab iron incident referred to above. This was, indeed, what happened.

Mr. Moseley did not live to visit the Supreme Court, as was his custom on opinion days, on January I5, I9I2, when the Act of 1908 was held valid, but he had established a precedent in the intervention of the United States on the side of the railroad employees, which was later followed by the Brotherhood of Railroad Trainmen in developing a similar plan which has assured these men and their families of able and honest legal representation in cases arising under the Act.

During the years from Ig08, when the Act first became law, to r930, when a Legal Aid Plan was finally adopted by the Brotherhood of Railroad Trainmen having the same purpose as the Moseley plan, it became increasingly evident that the national public policy, which the laws represented, was being widely flouted and defeated. Although the Brotherhoods had, by every means available, sought to inform their members of their rights under the law, fears as to their jobs and of the loss of such security as those jobs gave them had over the years been so instilled into them by their railroad employers, as to offer so much resistance to general accept-

${ }^{31}$ Id. at rio.

${ }^{32} 207$ U. S. 463 (1908); 223 U. S. I (IgI2). 
ance of advice, even from their union officials, that little headway could be made through these processes.

In these circumstances, the Brotherhood conceived it to be its duty to do everything that was essential and reasonably adapted to furnish any one of its members who had been injured in the course of his employment, or his next of kin in the event his injuries were fatal, assistance in adjusting or enforcing his claim against his employer. This was as certainly within the scope of its great purposes as were any of its activities affecting wages, hours, or conditions of work.

In 1928, ambulance chasing came under investigation by the courts of Ohio, New York, and other states. In the course of extended hearings on that subject, the activities of corporation claim agents were also investigated. In a partial report by Judge E. D. Fritch of Summit County, Ohio, who was in charge of the Ohio investigation, he observed: ${ }^{33}$

The great inequality in position and in bargaining power between the corporation claim agent and the injured person, is sufficient justification for such legal measures as will safeguard the injured person when he undertakes to make his own settlement.

Taking more or less drastic action against soliciting lawyers, and at the same time permitting claim agents to pursue their nefarious practices will not remedy the situation disclosed by the evidence. The public interest which of course includes that of injured persons, requires that both evils should be effectively dealt with.

In New York, Justice Wasservogel who was in charge of the investigation there, heard more than one thousand witnesses. His report was made the subject of an editorial in the American Bar Association Journal for November, 1928, entitled, "Nationwide War on "Ambulance Chasers." 'The writer of the editorial, after reviewing the report, said: ${ }^{34}$

It is worth noting that the improper practices found were not confined to the ambulance chasing lawyer-the attorney for the plaintiff "The evidence before me," says Mr. Justice Wasservogel in his report, "shows that casualty companies, transportation companies and other corporate defendants have engaged in practices equally reprehensible. Frequently the insurance adjuster races with the 'ambulance chaser' to the bedside of the injured person to obtain a release from him while he is overwrought and in pressing need of money. If a release cannot be obtained, the injured person is asked to sign a statement of the circumstances of the accident or is plied with questions. The oral or written statements extracted do not present a fair or complete picture. Nevertheless, they are used against the plaintiffs at the trial with exaggerated and harmful effect. Furthermore, repre. sentatives of some corporate defendants have not hesitated to effect settlements directly with claimants whom they knew to be represented by attorneys. This practice is unfair to such attorneys and deprives the clients of the benefit of their advice."

Under such conditions as those set forth in the remarks of counsel and in this extract from the Justice's report, it goes almost without saying that the victims of accidents have been notoriously exploited and that justice in most of such cases has become the merest travesty.

${ }^{33}$ I OHTO BAR Ass'N Rep. 301, 302, 304 (Nov. 1928).

${ }^{34} \mathrm{I}_{4}$ A. B. A. J. $56 \mathrm{I}, 563$ (1928). 
At the time these investigations were in progress and these reports were being made, the Brotherhood of Railroad Trainmen was carrying on an investigation of its own. As a result of its findings, the president of the Brotherhood in his annual report for I930, said: ${ }^{35}$

During the course of my several years experience as an officer of the Brotherhood it has come to my attention on a number of occasions, that injured members of the organization, and the dependents of members who had been killed while engaged in railroad service, had fared rather badly at the hands of railroad claim agents in some instances, as well as at the hands of so-called ambulance chasing lawyers in other instances.

In many cases settlements wholly inadequate in the light of the seriousness of the injuries and the responsibility of the employers had been made with members of the Brotherhood who were either entirely devoid of any knowledge of their rights in such matters, or who had been induced to make cheap settlements by misrepresentations indulged in by those who sought to effectuate these settlements. In still other cases, attorneys had either suffered defeat in law suits because of their inexperience or lack of ability to properly prosecute railroad damage claims.

In many cases attorneys had charged the injured men what appeared to be highly exorbitant fees for the service rendered.

To meet this situation, it was proposed that a Legal Aid Department be set up as part of the Brotherhood's activities in the interest of its injured members and their next of kin. The general counsel of the Brotherhood at that time, in justifying such a department, said in his annual report for $1929:^{36}$

The word "brotherhood" has a peculiarly significant meaning. It is supposed to indicate a fraternal spirit of helpfulness. Its purpose should be to render aid when distress comes; to offer help when help is really needed. A well man may be independent, but disability, sorrow and suffering create dependence. To desert a brother at such a time, when hardship threatens him and his family, is to make the term "brotherhood" seem like hollow mockery. The highest service any Brotherhood can render is to aid and protect its members when trouble comes, not alone in health, but in the hour of affliction. It undoubtedly would be a welcome thought to the members of the organization to know that when misfortune comes, they may turn for aid and advice to their own Brotherhood and receive the help and counsel they so sorely need. It is a matter of vital importance to our members that they shall not be kept in ignorance of their rights so that cheap and unfair settlements may be made. On the contrary provisions should be made for advising them of their rights and in assisting them to obtain them in so far as it is practical and consistent to do so.

The department was created by dividing the United States into sixteen regional areas, determined by: the density of membership in those areas; the character of the railroads, including mileage of tracks serving the area; and the accessibility of the lawyers selected, from different parts of the territory for which they were selected. Sixteen such areas, including the one wherein the Brotherhood had its principal

\footnotetext{
${ }^{35}$ Brotherhood of Railrond Trainmen, Report of the President 262 (i930).

${ }^{30}$ Brotherhood of Railroad Trainmen, Report of Tom J. McGrath, General Counsel, to A. F. WhitNey, President 12 (July, 1929).
} 
office, were chosen. The general counsel for the Brotherhood visited each of the selected areas and made an investigation of attorneys available as regional counsel. Their selection was based upon their reputation for skill and experience in handling personal injury claims, upon their reputation for honesty and fair dealing with their clients, and upon their being recommended by local federal and state court judges. Agreements were entered into with fifteen lawyers or law firms located in New York City, Boston, Minneapolis, Syracuse (New York), Cleveland, Chicago, Portland (Oregon), Kansas City (Missouri), St. Louis, Houston, Baltimore, Birmingham, Atlanta, San Francisco, and Denver. ${ }^{37}$

A regional counsel, at first, was required to handle cases on a contingent fee basis of 20 per cent of the amount recovered. He was required to remit 5 per cent to the department to cover the overhead expense and might keep 15 per cent for his fee. The department then required the observance of certain rules and practices which were a part of the contract. However, the attorney fulfilled every obligation he had undertaken to the Brotherhood when he fulfilled his full professional duty to the employee client.

Another feature of the plan was for the Brotherhood to employ skilled and experienced investigators and, when requested by the claimant, to send them into any regional area to assist an injured man or his next of kin in securing the facts and all other information, incident to and pertinent in the preparation of his case, for purposes both of settlement and suit in the event a fair amount could not be agreed upon in settlement. This was most important for the reason that all such facts and information in every case are collected by experts sent immediately by the railroads to the scene of the accident. The facts and information gathered by the legal aid investigators are turned over to the claimant or to any attorney employed to handle the case, whether it be regional counsel or someone else.

The plan at first was experimental and has been substantially changed over the years to remove every detail that could serve as the basis for honest criticism, either from the standpoint of law or of professional ethics. There is no longer any contract between regional counsel and the Brotherhood and no portion of the fees are now remitted to the Brotherhood. Its objective, however, is the same-to place the Brotherhood back of the Liability Act plaintiff where the Moseley plan placed the United States. The objective was immediately approved by the courts. ${ }^{38}$

It was not surprising, in view of the large economic interest involved, that the railroads overlooked the humanitarian nature of the objective and made the plan the subject of immediate and bitter attack. To give color to their attack, they adopted the view that it was an ambulance-chasing outfit and that regional counsel were in violation of canons of Ethics when they accepted the plan and represented Liability Act claimants under it. The railroads by emphasizing the ambulance-chasing and violation-of-legal-ethics theory, soon acquired as an ally, the organized bar, in their

\footnotetext{
${ }^{37}$ Brotherhood of Railroad Trainamen, Report of the President 266 (1930). 1933).

${ }^{38}$ Ryan v. Pennsylvania R: R., 268 Ill. App. 364 (I933); In re O'Neill, 5 F. Supp. 465 (E. D. N. Y.
} 
fight against this new champion of employees' rights-the Legal Aid Department of the Brotherhood. Members of local bar associations were persuaded that they were letting business get away from them. They came to believe that they had a vested interest in any case under the Act in which the cause of action arose in their territory. "These Regional Counsel in the big cities," they reasoned, "were "draining off' from their locality, business which should be kept at home. The big city lawyer was growing rich while they were growing poor."

The entire story of this sordid procedure is told in a resolution adopted by two Tennessee local bar associations on June 8 , I946. It was placed in the record at the trial of a chancery suit at Knoxville which will later be described. ${ }^{39}$ Its pertinence here is, first, its falsity as shown by comparison with the statements in the reports of the president and general counsel in their r930 reports and with the findings of the courts in the Ryan and O'Neil cases. ${ }^{40}$ Second, it leaves no question as to the real reasons behind the fight against the Legal Aid Department. As taken from the record in the chancery case where it became a public document, the two associations resolved:

Whereas, it has come to the attention of the Knoxville Bar Association that certain Railroad Brotherhoods have organized what is known as a Legal Aid Department ostensibly to assist the members of the organization and their dependents in securing damages for injuries sustained by railroad employees entitled to the benefits of the Federal Employers' Liability Act and for the beneficiaries of such employees who are fatally injured while engaged in the furtherance of interstate commerce, and such Legal Aid Department has appointed attorneys in various sections of the United States, who are designated as Regional Counsel for a certain territory and has also appointed Field Representatives in the several territories, and that whenever an injury or death occurs, the Field Representative calls on the injured employee or the beneficiary of such employee for the purpose of inducing said party to employ the so-called Regional Counsel, the result being that lawyers in foreign states are soliciting and taking away business from lawyers in states where the claims arise, and the practice of solicitation and transportation of claims is seriously undermining the traditional ethical standards of lawyers. By reason of these efforts on the part of the parties herein, many suits are brought in East St. Louis, Illinois and in other places far distant from the place where the accident occurred or the plaintiff resided.

Now, Therefore Be It Resolved, that we, the Knoxville and Knox County Bar Association, go on record as condemning this solicitation of claims in the manner set out in this resolution as being unethical and improper, and that a committee of three attorneys be appointed by the President of this Association to institute an injunction bill to enjoin such practices in the event any Regional Counsel or other representative of the Legal Aid Department comes into the jurisdiction of the Courts of Knox County; that copies of this Resolution be forwarded to Senators Kenneth D. McKellar and Tom Stewart, and to Congressman John Jennings, Jr., of the Second Congressional District of Tennessee, urging that legislation be passed in Congress confining the jurisdiction of suits under the

${ }^{30}$ Doughty v. Grills, in the Chancery Court for Knox County, Tennessee, before the Honorable Charles E. Dawson, Chancellor, No. 3435I, Injunction, pp. 24-25, Trial Court Record and pp. 84-85 of Record made up and certified by the Clerk of the Supreme Court of Tennessee, W. H. Earle, Aug. 25, r952.

${ }^{10}$ See note 38 supra. 
Federal Employers' Liability Act to the District Court of the district in which the injured plaintiff resided at the time of the injuries on which the action is based, or in the district in which plaintiff's intestate resided at the time of the injuries causing death; or such action may be brought in the District Court of the United States in the district where the cause of action arose; or such action may be brought in a State Court of competent jurisdiction in the county where the injured plaintiff resided at the time of the injuries, or where the plaintiff's intestate resided at the time of the injuries causing his death or in the county in which the action arose;

Be It Further Resolved, that a committee from the local Bar Association be given a copy of this Resolution and be authorized to present same to the appropriate committee of the Tennessee State Bar Association in convention at Memphis, and, if necessary, on the floor of the convention itself, urging that appropriate measures be taken to stop said unauthorized and unethical practices.

The committee appointed under the last paragraph of the resolution filed a suit in chancery at Knoxville in r950 against an investigator of the Legal Aid Department and a former local chairman of the local lodge of the Brotherhood of Railroad Trainmen, charging them with ambulance chasing in a complaint that closely paralleled the language of the resolution. The case was tried before the chancellor and a jury in March, I95I, five years after the resolution was adopted. The committee produced eighteen witnesses who testified on the merits of the case. The witnesses were local railroad men who had been injured and widows of railroad men who had been killed. All of them either settled, or sued on, their claims against the railroad. Many of them had known one or the other or both of the defendants for periods ranging from a few months to a lifetime. While it was shown that the defendants had, at the request of some of the witnesses, informed them of their right to secure advice from the Legal Aid Department and regional counsel about their cases; advised them that they need not employ regional counsel but could employ any lawyer of their choice, including regional counsel, to handle their claims; visited the injured in hospitals; attended and sent flowers to funerals; visited the homes of deceased brothers to deliver to the widow proceeds of insurance policies held by the deceased in the Brotherhood; adjusted deceased's retirement pay; and sent food and clothing to the children and widows of deceased men, not a single witness produced by the committee testified that the defendants had sought to solicit the claim of any witness for any attorney, as charged in the complaint.

The case went to the jury on special interrogatories. The jury was out only ten minutes. The verdict was not guilty. The chancellor dissolved a temporary injunction that had been entered when the complaint was filed and dismissed the suit. On appeal to the Court of Appeals in Knoxville, that court-not upon the pleadings and the evidence, but upon inferences drawn from a combination of assertions made in the resolution-selected bits of testimony of some of the witnesses, the affirmative portions of defendants' answers, a portion of the Brotherhood's constitution in evidence as to the Legal Aid Department, and a stipulation that no FELA suits had been filed in the circuit courts of Knox county or in the federal court in Knox county by injured Brotherhood members in the last ten years; and 
reversed the Chancellor's judgment. The Supreme Court of Tennessee denied a petition for certiorari, July $18,195^{2 .}{ }^{41}$

The Knoxville and Knox county bar had five years in which to find a witness that would pin the label of ambulance chaser on men employed by the Legal Aid Department to carry out its humanitarian objectives or upon that agency of the Brotherhood. They produced no such witness and won the case on the basis of the unfounded charges made in the resolution which were not proved by any evidence at the trial and which never could have rated any higher as admissible evidence than any other purely irresponsible propaganda.

This and other activities of the organized bar were in complete disregard of the right of claimants to sue the employer under the Act in East St. Louis, Illinois or in any other eligible forum, as well as their right to recover maximum damages in any suit they elected to file. These rights had only recently been reaffirmed by the Supreme Court in Boyd v. Grand Trunk Western Railroad, where the Court said:42

The vigor and validity of the Duncan decision was not impaired by Callen $v$. Pennsylvania R. Co., 332 U. S. 625 (r948). We there distinguished a full compromise enabling the parties to settle their dispute without litigation, which we held did not contravene the Act, from a device which obstructs the right of the Liability Act plaintiff to secure the maximum recovery if he should elect judicial trial of his cause. And nothing in Ex parte Collett, 337 U. S. 55 (1949), affects the initial choice of venue afforded Liability Act plaintiffs. We stated expressly that the section of the Judicial Code there involved, 28 U. S. C. $\$ 1_{404}(a)$, "does not limit or otherwise modify any right granted in $\$ 6$ of the Liability Act or elsewhere to bring suit in a particular district. An action may still be brought in any court, state or federal, in which it might have been brought previously." 337 U. S. at 60.

The right to select the forum granted in $\$ 6$ is a substantial right. It would thwart the express purpose of the Federal Employers' Liability Act to sanction defeat of that right by the device at bar. (Italics supplied.)

The suit was also in complete disregard of another right that claimants have under the Act itself. The Act provides:43

... whoever, by threat, intimidation, order, rule, contract, regulation, or device whatsoever, shall attempt to prevent any person from furnishing voluntarily such information to a person in interest ... shall, upon conviction thereof, be punished by a fine of not more than $\$ 1,000$ or imprisoned for not more than one year, or both such fine and imprisonment, for each offense. (Italics supplied.)

$\$ 1$ Certified Record, referred to in note 39 , supra, at 584 .

338 U. S. 263,266 (1949).

${ }^{43}$ This comprehensive language of Section ro, 53 STAT. 1404 (1939), 45 U. S. C. $\$ 60$ (1946), is one part of the 1939 Amendment that was essential to protect the injured employee or his next of kin from known devices designed to defeat claims under the Act by closing the avenues to facts and information incident to accidents causing injury and death. One known device was a rule that provided, "Employees who witness or have any knowledge of an accident, or of the facts involved, must not give information concerning it or talk about the occurrence to the injured person, lawyers, or to any other person or persons, unless legally required to so do, except only to company officials and claim agents. Information given to this company's representatives shall be as complete as possible and all facts must be stated whether favorable or unfavorable to anyone." See Hearings before a Subcommittee of the Senate Judiciary Committce on S. 1708, 76th Cong., 1st Sess. 21 (1939). rules.

The Knoxville Bar suit described in the text was in marked degree a substitute for these obstructive 
This chancery suit was addressed to the chancellor, keeper of the public conscience. The prayer for relief was in the name of justice, law, and professional ethics. After the evidence was in, the chancellor and twelve jurors, all citizens of Knox county, found nothing shocking to the public conscience and nothing in violation of law or professional ethics, and dispensed justice accordingly. The Court of Appeals, although it found "no evidence whatever in the record as to the constitution of the Legal Aid Department of the Brotherhood as to what services that department through its regional counsel performed, or was expected to perform, for the members," reversed on the theory that the Legal Aid Plan "tends to show a pattern with respect to efforts to have personal injury and death claims against railroads sucked out of Knox County." ${ }^{44}$ The two defendants, under this decision, are permanently restrained from exercising toward injured men and their next of kin that "fraternal spirit of helpfulness" indicated by the word "Brotherhood" upon which the general counsel in his Annual Report of 1929 rested his recommendation that the Legal Aid Department be created. One cannot review the record in this Knoxville proceeding, without a mental paraphrase of Madame Roland's famous apostrophe to Liberty ${ }^{45}$ just before her execution: Oh, Legal Ethics! What travesties are committed in thy name.

Regional counsel do not have a monopoly of these Liability Act claims. Many able, experienced, and honest lawyers throughout the nation by reason of established reputation are employed by injured men and their next of kin. But the Legal Aid Plan and the examples set by regional counsel, who work always within its spirit and purpose, have established a standard, both as to fees and treatment of these claimants, that has compelled even some out-and-out ambulance chasers to abandon to some extent the old methods that smacked so much of banditry, in favor of something like fair dealing. Moreover, unscrupulous claim agents find claimants better informed about their rights and less apt to fall into the traps described so accurately by Mr. Justice Wasservogel in his report referred to above.

This Legal Aid Plan of the Brotherhood can reasonably be given the chief credit for the real effectuation of this national public policy.

\section{III}

The creation of the Legal Aid Department by the Brotherhood furnished one of the major issues that gave rise to numerous controversies that punctuated the administration of this national policy after the adoption by Congress of the venue provision of the Act in Igro, and in particular after 1930. From that date down to this day, the Association of American Railroads, generally, and numerous individual railroads, in particular, have employed every conceivable method designed to obstruct or to destroy the rights guaranteed by the Act's provisions to injured railroad men and to their next of kin where injuries prove fatal.

In the first place, when cases reached the courts, railroad lawyers in their failure

4 Certified Record referred to in note 39, supra, at 448 .

${ }^{40} \mathrm{O}$ Liberty! What crimes are committed in thy name. 
or refusal to understand or to be guided by the spirit and purpose of the law, grasped at every straw in the wind of hostile judicial philosophy and counted every ruling tending to weaken the law or to reimpose old common-law defenses as a crack in the wall of the edifice of justice to these men erected by Congress in this legislation. The restrictive interpretations of the law thus gained were again swept away by the 1939 Amendment. ${ }^{46}$

In the second place, many other devices and procedures were drawn from the legal and propaganda arsenals of the railroads and the organized bar for the purpose of preventing Liability Act claimants from breaking out of areas where attorneys with skill and experience in handling these cases were usually under retainers by the railroads and where the lawyers available to these claimants were not competent to advise them as to their rights and to secure the maximum recovery for injury and death to which they were entitled under the Act. There was what became popularly known as the "Rock Island Release," in which an injured man was induced, for the smallest consideration he would accept, to sign a written agreement that, if his claim could not be amicably settled, he would bring suit in a particular court or in the courts of a particular county, district or state. It took years to defeat this device in the courts, but it was finally held invalid by the United States Supreme Court in Boyd v. Grand Trunk Western Railroad.77 There was the attempt, by injunction, to defeat the purpose of the Act, wherein the plaintiff was enjoined from prosecuting a suit brought in any court outside the "point, place or state" where plaintiff lived or the accident happened. This practice ended in failure when it was ruled out by the Supreme Court of the United States in two decisions. ${ }^{48}$ The device is now being revived. In Pope v. Atlantic Coast Line Railroad, ${ }^{49}$ the Supreme Court of Georgia held that the Kepner and Miles decisions ${ }^{50}$ were no longer controlling since Congress in its revision of the Federal Judicial Code for the convenience of parties and witnesses in the interest of justice, gave federal district courts the power to transfer any civil action to any other district or division where it might have been brought. $^{51}$ The Supreme Court of the United States has granted certiorari and the case is now pending in that court. ${ }^{52}$ There was the attempt to use the doctrine of forum non conveniens which ended when the Supreme Court of the United States held that the doctrine was subject to one invariable limiting principle-namely, that it was not applicable in cases arising under the FELA...3

The attack upon the venue provision had, in the meantime, been shifted to direct action. The Association of American Railroads had acquired as an ally the organized bar, in so far as the leadership of its national and state bodies was concerned.

"Wilkerson v. McCarthy, 336 U. S. 53, 69 (1949).

${ }^{47} 338$ U. S. 263 (I949).

${ }^{48}$ Baltimore and O. R. R. v. Kepner, 3 I4 U. S. 44 (1942): Miles v. Illinois Central R. R., 3I5 U. S. 698 (1942).

${ }^{40} 209$ Ga. 187, 7I S. E. 2d 243 (1952).

to See note 48 sipra.

6128 U. S. C. $\$ \mathrm{I}_{404}(\mathrm{a})(\mathrm{9} 948)$.

62344 U. S. 863 (1952).

${ }^{53}$ United States v. National City Lines, 334 U. S. 573, 596 (1948). 
The Knoxville bar put the resolution quoted above in the hands of Congressman John J. Jennings, Jr., a resident of Knoxville, representing in Congress the Second Congressional District of Tennessee. He introduced a bill, closely following directions contained in the resolution, in the House as H. R. 1639, which in the Senate became S. $1567 .{ }^{54}$ The theory of the proponents was that repeal of the venue provision would end ambulance chasing in connection with the claims and would also end the Brotherhood's Legal Aid Department. The array of proponents and opponents of the bills appearing at the hearings before congressional committees led to this accurately characterized description of the fight that ensued as a result of the proposed legislation: $:^{55}$

In this battle of the titans, the organized railroad transportation industry and the organized legal profession joined in supporting the proposal and were opposed by organized railway labor.

It is of interest to note here that a special assistant to the Attorney General of the United States presented a statement with respect to S. 1567 at the hearing before the Senate Committee on the Judiciary in which the issues raised by the legislation were analyzed and questions were raised as to the desirability of the changes in legislative policy represented by the proposed repeal of the venue section of the Act. ${ }^{\text {.0 }}$

Congressman Jennings, with the resolution of the Knoxville bar as a foundation and guide, personally wrote "the Presidents of the Bar Associations of each of the $4^{8}$ states and to hundreds of the presidents of the local bar associations throughout the United States" in order to secure approval of H. R. I639. He received resolutions from most of the state bar associations, from the American Bar Association, and from hundreds of county and city bar associations. ${ }^{57}$ The propaganda he sent out and his testimony in the transcripts of hearings before congressional committees labeled the Brotherhood Legal Aid Department as a nationwide racket, carrying on a nefarious practice of active solicitation of cases arising under the Federal Act; and depriving the local lawyer of litigation which in his view properly should be handled in the forum where an accident occurred, or where the injured party resided, at the time of the accident. ${ }^{58} \mathrm{He}$ and other proponents of the bill, in order to strengthen these claims as to the Legal Aid Department, used the skilled propagandist's technique of establishing guilt by association. A notorious ambulancechasing case then pending in Chicago was dramatically interwoven with charges of running, soliciting, and chasing of cases made against regional counsel of the Brotherhood and brought to the attention of the committees by a former Chief Justice of the Supreme Court of Illinois who had been employed by the railroads to prosecute

\footnotetext{
${ }^{5}$ Hearings before a Subcommittee of the Senate Judiciary Committee on S. 1567 and H. R. 1639, 8oth Cong., 2d Sess. (1948).

"Mangan, Federal Legislation, 37 Geo. L. J. 43 (1948).

${ }^{50}$ Hearings, supra note 54 , at 12 .

${ }^{67}$ Hearings before Subcommittee No. 4 of the House Judiciary Committee on H. R. 1639, 80th Cong., Ist Sess. 13 (I947).

Es Id. at 12 .
} 
the case. ${ }^{59}$ References throughout the testimony of the various proponents of the bill are made to regional counsel as ambulance chasers who "drain off" legal business from local lawyers, enriching themselves and impoverishing the local lawyers. ${ }^{60}$ These prodigious efforts thus made to destroy the venue provision of the Act failed when the bill died in committee in $1948 .^{61}$

Here again the reasons given by the proponents of H. R. I6 39 and S. I567 for repealing the venue provision of the Act remind one of the historic utterance of Madame Roland as she bowed before the clay statue of Liberty in the Place de la Revolution on her way to the guillotine.

In I939, near the end of the Seventy-Sixth Congress, the need for a comprehensive revision of the United States Judicial Code (28 U. S. C.) was recognized. In that and future Congresses, appropriate legislation was passed to provide for such a revision. The statute representing such a revision went into preparation in 1944. It was completed, introduced in Congress as H. R. 3214, and was pending in Congress simultaneously with the Jennings Bill, H. R. I639. Jennings, who introduced H. R. I639 in the House, and at least one of the noted lawyers who appeared before the House and Senate Committees on the Judiciary to urge its passage and who was then representing one of the big western railroads in a notorious ambulance-chasing case in Chicago, were on important committees in charge of the revision of the Judicial Code. The Revision statute became law in June I948, effective September I, $1948 .^{62}$

After the new Code became law, it was discovered by railway labor which was not represented on the revision staff or on any committee in charge of the revision, that it contained the following harmless-appearing provision: ${ }^{63}$

For the convenience of parties and witnesses, in the interest of justice, a district court may transfer any civil action to any other district or division where it might have been brought.

The Reviser, in his note to this section, stated that this provision had been drawn in accordance with the doctrine of forum non conveniens and he cited Baltimore \& Ohio Railroad v. Kepner, ${ }^{64}$ as an example of the need for such a provision. The controversy that arose, both in the federal and state courts, as to the effect of this provision on FELA cases was settled by the Supreme Court of the United States in Ex parte Collett, ${ }^{65}$ where the Court held that federal courts were given discretion by the provision to transfer FELA cases along with all other civil cases, where the provision applies. The Court took note in its opinion in Ex parte Collett, of the assurances given to Congress by the revision staff and members of the committees of the Senate and House that changes in the Code that could be deemed contro-

\footnotetext{
${ }^{60} \mathrm{Id}$. at 16; see Hearings, stupra note 54 , at 38 . See also Atchison, Topeka and Santa Fe R. R. v. Andrews, 338 III. App. 552,88 N. E. 2 d 364 (I949).

${ }^{\circ}$ See Hearings before House and Senate Committees on the Judiciary on H. R. 1639 and S. 1567, supra, notes 54 and 57 .

a1 See 62 Star. 989 , amendment of $\$ 6$, June $25,1948,45$ U. S. C. A. $\$ 56$ (1952).

0228 U. S. C. $\S$ I et seq.

3 I $_{4}$ U. S. 44 (I942). 
versial had been studiously avoided. Congress was assured that, though changes and improvements in existing law had been made, such as had been made were of a wholly non-controversial nature. The Court, however, held in effect that these assurances could not be considered as of any importance in deciding the case for the reason that the provision was unanimously approved by Congress and that this unanimity demonstrated that there was, in fact, nothing controversial about the provision. The Court could have found, had it looked far enough, that the absence of controversy resulted solely from the fact that only one side to the controversy was present at every stage of the process of inserting this provision in the Revised Code, from its initiation to its enactment as a part of the Code. Railway labor was not there and had no warning that it needed to be there. Even the Department of Justice which was affected by the provision in a manner very nearly as vital as railway labor, although it studied and approved the complete Code, was not aware of the provision's insidious character. These are the reasons for the failure of the provision to excite controversy in Congress when the Code became law.

In Hayes $v$. Chicago R. I. \& P. Railroad, the first case in which Section I404(a) was applied, the court in allowing a motion to transfer under the provision, said: ${ }^{\circ 6}$

There is no basic reason why plaintiffs in cases under the Federal Employers' Liability Act should not be subject to the same equitable doctrine of transfer as applies to all other civil cases now that Congress has enacted a statute which indicates no exception to the application of that principle.

Later the Supreme Court in Ex parte Collett held that the provision does not limit or otherwise modify any right granted in Section 6 of the Act or elsewhere to bring suit in any particular district.

In Naughton $\nu$. Pennsylvania Railroad, in denying a motion to transfer under $\S 1404(a)$, the court said: ${ }^{67 i}$

The view contended for by the defendant would come close to making $\$ 1_{404}$ (a) a venue statute, under which the court, after striking a nice balance of conveniences, would be bound to limit the plaintiff to a single jurisdiction. If that had been the purpose, the statute would have directed the courts to make transfers to the most convenient jurisdiction-a very different question from that involved in the doctrine of forum non conveniens.

The evolution of the interpretation and construction process in dealing with this provision has carried the courts to the position that the power to transfer should be exercised only in exceptional cases and to correct abuses. ${ }^{08}$ However, under its influence, application of the doctrine of forum non conveniens now rests upon the policy and procedures in the several states rather than upon federal policy. ${ }^{60}$ But it still remains true that in the $x 939$ amendment to the Act, which was the last time the Act has been in need of repair, Congress not only adhered to its previous views,

${ }^{68} 79$ F. Supp. 821, 824 (D. Minn. 1948).

${ }^{67} 85$ F. Supp. $76 \mathrm{r}, 764$ (E. D. Pa. 1949).

${ }^{\circ 8}$ See United States v. Scott and Williams, 88 F. Supp, 53I, 534 (S. D. N. Y., I950).

${ }^{60}$ Missouri ex rel. Southern Ry. v. Mayfield, 340 U. S. I (1950). 
but greatly strengthened and extended the protective features of the Act. It was still acting under what it deemed to be the urge of the strongest and highest considerations of justice and the promotion of the public welfare.

Thus, the integrity of the law, which was the chief concern of the Moseley and Brotherhood Legal Aid plans, has been maintained through nearly a half century of bitter controversy. As a result, the stringent liability placed upon the railroads with the view that it would "compel the highest safeguarding of the lives and limbs of the men in this dangerous employment," has borne visible fruit. In the year 1907, when the Act of 1906 was under attack and the Act of 1908 was in the making, the casualty lists showed 4,534 men killed and 87,644 injured. In 1950, with a greatly increased number of men exposed to that danger, there were 392 killed and 22,586 injured. ${ }^{70}$

As was said in the beginning, the survival of such a policy when expressed in a statute in the face of continuous and concerted attack upon it by those who profess a philosophy hostile to it and by powerful interests claiming to be adversely affected by it, through long periods of time during which the policy has been steadily strengthened and broadened by the law-making body which declared it and by the courts charged with the duty of construing it, constitutes the strongest proof of the soundness of the policy. Congress has never departed from the high notion of its handiwork held when this national public policy was announced in IgIo and the courts have settled down to that liberal construction of the law that is held to be warranted by its humanitarian objectives. This national public policy has been fully vindicated.

\section{IV}

This legislation has also survived the onslaughts of those disciples of change who are easily persuaded that principles, unlike good wine, do not improve with age. Let there be a condition that excites human propensities toward reform; a consequent social problem; existing remedies keyed to the instinctive conflict between those to be benefited and those who are to bear the costs of the benefits; a proposed remedy that promises an expeditious and a more or less automatic solution, if these conflicts be disregarded; an occasion for claiming that an idealistic reform is to be consummated-and these disciples of change at once espouse the cause of promoting the adoption of the new remedy. This is not said in disparagement of idealism. It is idealism that sets the pace for practical measures to meet any problem. It was Edward A. Moseley's practical idealism that in the face of intolerable conditions, led to the Safety Appliance, Federal Employers' Liability, and other acts that now stand as models for measures that are supplanting workmen's compensation laws.

The critics of the principle that fault is requisite to liability-written into the FELA-have been overruled by time and experience. Congress, when the Employers' Liability Acts were under consideration, had before it the legislation of all of

\footnotetext{
${ }^{70}$ Interstate Commerce Commussion, Accident Bull. No. IIg (Appendix A, SumMary Statements of Railway Accidents in the United States for the Years i888-1950) II2 (I95 1 ).
} 
the nations of continental Europe, Great Britain and its dominions, and the several states of this nation, dealing with methods of compensation for accidental injury and death. ${ }^{71}$ In the forty-four years since the Liability Act was passed in 1908 , there have been twenty-six bills, introduced in twelve Congresses, to replace it with workmen's compensation acts. ${ }^{72}$ It is now advocated that the workmen's compensation principle of liability without fault be extended to cover all cases of accidental injury and death, traditionally covered by the common law of torts. ${ }^{73}$

The principle of liability without fault was society's original method of compensation for any sort of damage done to one person by another. He who innocently caused damage to another was required to make the injured person whole. The innocent was in a position no different from the wrongdoer of that time. This principle was abandoned about the year I 400 A.D. and replaced by the principle that fault is essential to create liability. The modern workmen's compensation acts, five hundred years later, in principle, gave recrudescence to this ancient rule of law. ${ }^{74}$ The two principles have been competing for survival in this country for a half century and in particular ever since the enactment of the present FELA.

Recent important events have made it unnecessary to re-argue the relative merits of these two principles. In July, 1946, the Departmental Committee on Alternative Remedies in England, was instructed among other things: ${ }^{75}$

(a) To consider, having regard to the observations on the subject of alternative remedies in the Report on Social Insurance and Allied Services, and to any developments which announcements by the Government show to be contemplated in connection with that Report, how far the recovery or proceedings for the recovery of damages or compensation in respect of personal injury caused by negligence should affect, or be affected by, the provision made or proposed to be made under Workmen's Compensation legislation or under any social insurance or other statutory schemes for affording financial or other assistance to persons incapacitated by injury or sickness, or their dependents:

(b) To consider, having regard to any relevant observations in the aforesaid Report and in the Report of the Law Revision Committee on Contributory Negligence, whether in the case of injuries to workmen due to their employment, any alteration is desirable in the law governing the liability of employers and third parties to pay damages or compensation to workmen and their legal representatives and dependents, independently of the Workmen's Compensation Acts.

As a result of the study made under these instructions, there was submitted to the

${ }^{71}$ Hearings before Subcommittee of Committee Having Under Consideration H. 239 and S. 156 and S. 1657 Relating to Liability of Common Carriers by Railroads in District of Columbia and Tcrritories and Common Carriers by Railroads Engaged in Commerce Between States and Between States and Foreign Nations to Their Employees, 59th Cong., ist Sess. (1906); Hearings before the House Iudiciary Committee on H. R. 17036 Relating to Liability of Common Carriers to Employees, 6oth Cong., ist Sess. (I908).

${ }^{72}$ Pollack, Workmen's Compensation for Railroad Work Injuries and Diseases, 36 CoRnelL L. Q. 236, 271 (195r).

${ }^{73}$ Malone, Workmen's Compensation Law, 9 NACCA L. J. 20 (1952).

${ }^{74}$ Smith, Sequel to Workmen's Compensation Acts, 27 Harv. L. Rev. 235, 239 (1913-1914).

75 Final Report of the Departagental Committee on Alternattve Remedies, CMd. No. 6860 (I946). 
Minister of National Insurance by Sir Walter J. Monckton, Chairman of the Committee, a Final Report, in July, I946, ${ }^{76}$ which led to the enactment by Parliament of The Law Reform (Personal Injuries) Act of $1948{ }^{77}$ This law repealed all workmen's compensation acts. ${ }^{78}$ It became the master statute of a group of laws closely similar to the group of laws enacted by Congress-the Safety Appliance Acts, ${ }^{\text {79 }}$ the Railroad Retirement Act, ${ }^{80}$ and the Railroad Unemployment Insurance Act ${ }^{81} \longrightarrow$ of which the FELA is the master statute.

The English Act of 1948 provides for recovery of damages resulting from the negligence of the employer. The injured employee may draw upon the insurance fund for disability caused by his injuries to sustain him until his claim is settled or he collects a judgment at the end of a law suit. From the proceeds of recovery he repays the amount drawn from the insurance fund. Thus the very citadel of workmen's compensation has returned to the principle that fault is requisite to liability.

A study has just been completed under the authority of the University of Illinois in which the superiority of the FELA system over that of the workmen's compensation system is conceded. The authors of the Report resulting from the study quote, approvingly, the following conclusion of "an experienced compensation attorney" as to the workmen's compensation system $:^{82}$

The utopia of speed and simplicity sought by the legislators has eluded the injured worker, and legal representation remains indispensable. In fact, boards or commissions generally have come to frown upon an employee's appearing without counsel, or a layman's attempting to practice before them.

A substantial percentage of these railroad cases arises under the Safety Appliance Acts, under the provisions of which the duty of the carrier is absolute and proof of negligence is not required. ${ }^{\mathbf{3}}$ Even where the carrier is under the qualified duty to use ordinary care, the injured railroad employee and his next of kin under the Federal Act have experienced much less difficulty in establishing that injury and death resulted, "in whole or in part" from the employer's negligence, than is met under the workmen's compensation system by a claimant in establishing that the accident arose "out of and in the course of employment." As Mr. Justice Murphy said: ${ }^{83}$

The statutory phrase "arising out of and in the course of the employment," which appears in most workmen's compensation laws, is deceptively simple and litigiously prolific.

${ }^{70}$ Ibid.

${ }^{77}$ Acts of 9 \& Io Geo. 6, c. 62, iI \& I2 Geo. 6, c. 4I. See Butterworth's Twentieth Century STATUTES 1592 (1948).

${ }^{78}$ Butrerworth, op. cit. supra, at 1594 , Historical Note.

${ }^{70} 27$ STAT. 53 I (1893), as amended, 45 U. S. C. $\$ \$ 1-46$ (1946).

${ }^{\text {so }} 50$ STat. 307 (1937), as amended, 45 U. S. C. $\$ 238$ et seq. (1946).

${ }^{31} 52$ STAT. 1094 (1938), as amended, 45 U. S. C. \$35r et seq. (1946).

${ }^{83}$ Alfred F. Conard and Robert I. Merr, Costs of Administering Reparation for Work Injurues in Illinois 9 (Graduate College, Universtry of Illinois, r952). See also Conard, Workmen's Compensation: Is It More Efficient Than Employer's Liability?, 38 A. B. A. J. IOI (1952).

${ }^{82 a}$ O'Donnell v. Elgin, Joliet \& Eastern Ry., 338 U. S. 384 (1949).

${ }^{83}$ Cardillo v. Liberty Mutual Ins. Co., 330 U. S. 469, 479 (I947). 
The truth of this statement is fully borne out by the space in the American Digest system required in the digest of workmen's compensation litigation-2253 pages in the Fourth Decennial and $345^{2}$ pages in the Fifth Decennial.

The litigious aspect of the workmen's compensation principle is not its worst feature. Its awards are wholly inadequate and its administration, according to the Illinois University study, is much more expensive than is the administration of the Federal Employers' Liability Act's methods and procedures. ${ }^{87}$ Comparisons are not necessary here. Those who are interested in studies reflecting the adequacy of awards under the two systems are referred to volumes I to 9 of the NACCA Law Journal where awards under both systems are listed and appropriate comments are made.

The claimant under the FELA who takes his case to regional counsel of the Brotherhood or to any reputable, skilled and experienced lawyer will secure verdicts in court adequate to give him fair compensation for injury or death. The amounts recovered are sustained so long as they do not strike the court as monstrous. In Affolder v. New York, Chicago and St. Louis Railroad, where injuries resulted in the loss of one leg, the jury returned a verdict for $\$ 80,000.00$. The United States Court of Appeals, Eighth Circuit had reversed. ${ }^{85}$ The Supreme Court granted certiorari, and in reversing the judgment of the Court of Appeals, said: ${ }^{88}$

We agree with the Court of Appeals that the amount of damages awarded by the District Court's judgment is not monstrous in the circumstances of this case. Barry $v$. Edmunds, II6 U. S. $55^{\circ}$ (1886). Accordingly, the judgment of the Court of Appeals is reversed and that of the District Court affirmed.

In such cases, when the injured man leaves regional counsel's office with his check, the amount of that check represents approximately 75 per cent of the amount recovered. When he leaves the office of any other skilled, experienced lawyer, the amount of his check represents from approximately 65 to 75 per cent of his recovery. This is true whether the amount recovered is by suit or in settlement.

The influence of affirmance of adequate verdicts and the settlements secured through able counsel, enables injured men and their next of kin to make many satisfactory settlements without the necessity of employing counsel. Conservatively, as a result of such verdicts and settlements in these cases, 95 per cent of claims are settled, either without suit, or if suit is brought, before the case goes to the jury. Moreover, what is still more important, the effect of these adequate settlements and verdicts is to cause the railroad employer to provide the highest safeguards to the lives and limbs of railroad workers that care, diligence, and efficiency can produce.

Any regional counsel or any other able and experienced attorney who handles these cases will testify that the number of cases in which no recovery can be had by reason of inability to prove negligence and that injury or death was due in whole or

\footnotetext{
${ }^{84}$ Conard and MEHR, op. cit. supra note 82 , at 43 , Table 7.

${ }^{86} 174$ F. 2d 486 (8th Cir. I948).

${ }^{\text {so }} 339$ U. S. 96 , I0I (1950).
} 
in part to that negligence are small. Yet, the courts have not made this Federal Act into a workmen's compensation law. ${ }^{87}$

While government has rarely ever adopted a measure designed as a solution of some important social problem that could not be improved with time and experience, there has not yet been found any method of compensating injured railroad men and their next of kin that can be substituted satisfactorily for that provided by Congress in the FELA and the group of laws designed to supplement it. It has proved worthy to stand beside and in a position of equality with the remedies open to seamen, both in admiralty and in the law courts.

Since I888, when, under Mr. Moseley's directions, scientific methods of keeping statistics of operative railroad casualties were adopted, there have been I25,000 operative railroad men killed and 4,293,326 injured in reportable accidents. ${ }^{88}$ It is the personal, social and economic impact of this staggering human overhead of an industry, in which these millions suffered and died at their posts of duty, and in which their successors serve while faced with a similar fate, that has determined operative railroad men to fight for improvement in and for the preservation of this national public policy.

${ }^{87}$ See Myers v. Reading Co., $33 x$ U. S. 477,485 (1947); Wilkerson v. McCarthy, 336 U. S. 53, 6r62 (I948).

${ }^{8}$ Interstate Commerce Commission, Accident Bull. No. il9 (Appendix A, Summary Statements of Railway Accidents in the United States for the Years i 888-I950) xI2 (x95I). 